\title{
SISTEM PENGOBATAN TRADISIONAL (studi Kasus di Desa Juntinyuat, Kecamatan Juntinyuat, Kabupaten Indramayu)
}

\author{
Traditional Medicine \\ (A Case Study in The Village of Juntinyuat, District of Juntinyuat, Regency of \\ Indramayu)
}

\author{
Oleh Yanti Nisfiyanti
}

Balai Pelestarian Sejarah dan Nilai Tradisional Bandung

Jln. Cinambo No. 136 Ujungberung Bandung

Email: yantinisfiyanti@ymail.com

\begin{abstract}
Abstrak
Sejak dahulu nenek moyang kita telah menciptakan berbagai ramuan obat yang berasal dari tumbuh-tumbuhan untuk mengobati sakit atau memelihara kesehatan. Tradisi tersebut di antaranya tertulis dalam naskah-naskah kuno yang tersebar di berbagai daerah di Indonesia. Di antaranya disebutkan berbagai jenis penyakit yang sering diderita masyarakat dan berbagai jenis tumbuhan yang diramu untuk obatnya. Dalam perkembangannya, hasil riset para ahli mengungkapkan bahwa herbal yang digunakan dalam pengobatan tradisional tersebut terkandung berbagai zat yang bermanfaat bagi kesehatan. Dari hasil penelitian diketahui bahwa sistem pengetahuan tentang pengobatan tradisional di Desa Juntinyuat merupakan warisan dari leluhurnya. Masyarakat Juntinyuat hanya meneruskan tradisi pengobatan yang sudah ada. Pengobatan tradisional yang mereka lakukan mencakup semua jenis penyakit yang diderita. Mulai dari penyakit ringan sampai penyakit yang berat, bahkan untuk memelihara kebugaran dan kesehatan badan. Mereka merasakan manfaat pengobatan tradisional meskipun tingkat kemanjuran obat tersebut memerlukan waktu yang lebih lama. Bahkan lebih efektif digunakan untuk memelihara kesehatan daripada untuk penyembuhan. Dari situ muncul tradisi minum jamu di kalangan masyarakat untuk memelihara kesehatan badan. Pengobatan tradisional ditempuh sebagai upaya pertolongan pertama atau darurat sebelum berobat ke medis. Namun demikian, apabila penyakit tidak dapat disembuhkan secara medis atau pengobatan secara medis tidak terjangkau biayanya, masyarakat kembali lagi ke pengobatan tradisional.
\end{abstract}

Kata kunci: pengobatan tradisional, herbal, sistem pengetahuan.

\begin{abstract}
Our ancestors has created herbal remedies either to cure illnesses or for health care. Those recipes were written in old manuscripts and are scattered around Indonesia, mentioning some common diseases and herbs that cure them. Modern research reveals that herbs used by our ancestors contain elements that are beneficial to human health. The result of this research shows that knowledge system about traditional medicine in Desa/village Juntinyuat is inherited from their ancestors. The remedy covers ailment to severe diseases,
\end{abstract}


as well as health care and body fitness. Although it takes quite long enough to get well, the people of Juntinyuat feel the remedies are very useful. They are even more useful for health care than to cure illnesses. This fact leads to practice of taking jamu (herbal medicine) for caring health, and this is the first aid before seeing the doctor. But, if seeing the doctor does not work and the cost is considered high, they will turn back to the traditional medicine.

Keywords: traditional medicine, herbal, knowledge system.

\section{A. PENDAHULUAN}

Pengobatan tradisional adalah bagian dari kebudayaan bangsa Indonesia yang diturunkan dari generasi ke generasi, baik secara lisan maupun tulisan (Djlantik, 1983). Obat-obatan tradisional yang terbuat dari tumbuhan tersebut mudah didapat di sekitar tempat tinggal dan juga secara ekonomi terjangkau bila dibandingkan dengan obat dan pengobatan modern saat ini. Selain itu, obat-obat tradisional relatif aman karena tidak dicampur dengan bahan kimia sehingga tidak berefek samping seperti halnya obat-obatan modern.

Pengetahuan tentang pengobatan tradisional merupakan tradisi warisan leluhur bangsa Indonesia. Selain telah diturunkan secara lisan, turun-temurun dari generasi ke generasi, ilmu pengobatan tradisional telah dicatat dalam naskah-naskah kuno, di antaranya naskah berbahasa Sunda yang dinamakan Kumpulan Mantra, Paririmbon, dan Petangan. Naskah-naskah tersebut berisi mantera-mantera yang berkaitan dengan pengobatan, membasmi wabah penyakit, dan membuang racun.

Hingga kini, pengetahuan tentang obat dan pengobatan secara tradisional masih digunakan oleh sebagian masyarakat meskipun terbatas di kalangan tertentu saja untuk mengatasi sakit dalam kondisi darurat dan memelihara kesehatan. Selain itu, berbagai jenis tumbuhan yang menjadi tumpuan pengobatan tradisional terus dikembangkan untuk kepentingan pengobatan modern. Oleh karena itu, keberadaan obat dan pengobatan tradisional semakin mendapat pengakuan di bidang kesehatan, menyusul adanya hasil-hasil riset kesehatan yang menyimpulkan berbagai tumbuhan sangat bermanfaat bagi kesehatan dan kecantikan. Hasil riset Supriadi dan kawankawan (2001) menyimpulkan bahwa sebanyak 78 spesies tumbuhan telah digunakan oleh 34 etnis untuk pengobatan penyakit malaria; 133 spesies tumbuhan digunakan oleh 30 etnis untuk pengobatan penyakit demam; 110 spesies tumbuhan digunakan oleh 30 etnis untuk pengobatan penyakit gangguan pencernaan; dan 98 spesies tumbuhan digunakan oleh 27 etnis untuk pengobatan penyakit kulit. Hasil-hasil riset tersebut diperkuat dengan pemaparan unsur-unsur kandungan yang terdapat dalam tumbuhan-tumbuhan tersebut.

Sebagai contoh, lidah buaya atau nama latinnya aloevera mengandung zat-zat yang dapat berfungsi sebagai antioksidan untuk mencegah penuaan dini, serangan jantung, dan beberapa penyakit degeneratif. Di bidang kecantikan, para ahli menciptakan bahan dari lidah buaya ini sebagai obat penyubur rambut dan suplemen makanan.

Meskipun informasi obat-obatan dan pengobatan tradisional telah banyak dipublikasikan, potensi obat dan pengobatan tradisional masih bisa digali dari berbagai daerah khususnya di Jawa Barat untuk memperkaya khasanah obat dan pengobatan tradisional yang telah ada. Salah satu daerah di Jawa Barat yang hingga kini masyarakatnya masih menggunakan obat tradisional secara turun-temurun adalah masyarakat di Kabupaten Indramayu. Upaya untuk menyelamatkan warisan budaya leluhur terus dilakukan, baik oleh kelompok maupun perorangan, yang menerapkannya dalam kehidupan sehari-hari.

Sehubungan dengan latar belakang permasalahan yang telah dikemukakan, maka dilakukan penelitian sistem pengobatan tradisional di Kabupaten Indramayu dalam hal ini mengambil lokasi di Kecamatan Juntinyuat. Tujuan dari penelitian ini untuk mengetahui persepsi masyarakat tentang sehat dan sakit, penyakit-penyakit yang diobati dengan obat tradisional, dan bahan-bahan yang dapat digunakan sebagai obat, serta cara pengobatannya. Oleh karena 
itu, ruang lingkup penelitian dibatasi seputar kebiasaan yang dilakukan oleh masyarakat Juntinyuat dalam mencegah dan mengobati sakit sehubungan dengan pemakaian obat tradisional.

Adapun metode yang digunakan deskripsi analisis, yaitu menggambarkan fenomena yang sedang berlangsung, dalam hal ini kehidupan masyarakat Juntinyuat sehubungan dengan kebiasaan mereka dalam memelihara kesehatan dan mengobati sakit menggunakan cara-cara tradisional. Kemudian akan dijelaskan hubungan antarunsur di dalamnya dalam hal ini mengapa mereka melakukan demikian. Dalam menjelaskan hubungan antarunsur tersebut digunakan teori Kluckhohn dan Florence Kluckhohn, istrinya, tentang hubungan manusia dengan alam (MA) bahwa manusia harus mampu menjajagi rahasia-rahasia alam dan memanfaatkannya untuk keperluan hidupnya atau hidup selaras dengan alam. (Kluckhohn dalam Koentjaraningrat, 2007:81)

\section{B. HASIL DAN BAHASAN}

Desa Juntinyuat merupakan salah satu wilayah di Kecamatan Juntinyuat, Kabupaten Indramayu yang wilayahnya meliputi daerah sawah, pantai, dan daratan. Jarak pemerintahan desa ke kecamatan $0 \mathrm{~km}$ karena berada di wilayah Kecamatan Juntinyuat $(0 \mathrm{~km})$, jarak ke desa terjauh 7 $\mathrm{km}$, dan jarak ke kantor kabupaten $18 \mathrm{~km}$. Desa Juntinyuat memiliki satu dusun. Luas wilayah Desa Juntinyuat 2,77 km2 dengan jumlah penduduk 6.187 jiwa terdiri atas 2.967 laki-laki dan 3.220 perempuan serta jumlah kepala keluarga 1.935. Adapun jenis mata pencaharian penduduk beragam, namun mayoritas petani dan nelayan.

Tradisi yang masih mereka jalankan di antaranya menerapkan pengetahuan tentang obat dan pengobatan tradisional, baik dalam kehidupan sehari-hari maupun peristiwa-peristiwa tertentu, seperti melaksanakan upacara untuk mencegah wabah penyakit dalam upacara mapag tamba dan baritan. Mapag Tamba sebuah tradisi yang dilaksanakan untuk mengusir penyakit yang biasa menyerang tanaman padi. Upacara ini dilaksanakan setelah ngoyos, yaitu membersihkan rumput-rumput liar di antara tanaman padi. Teknis upacara dengan menyiramkan air tamba atau obat padi ke beberapa lokasi air yang mengalir ke sawah melalui tata cara yang biasa dilaksanakan secara turuntemurun. Sebelum air tamba dituangkan ke pematang, dilaksanakan dahulu selamatan dengan membacakan mantera oleh pemimpin upacara.

Upacara Baritan merupakan tradisi masyarakat setempat dalam menolak wabah penyakit yang biasa menyerang manusia. Namanya berasal dari kata burit, yaitu waktu menjelang magrib. Upacara dilaksanakan di perempatan jalan dengan tata cara yang biasa dilaksanakan secara turun-temurun.

\section{Persepsi Masyarakat tentang Sehat dan Sakit}

WHO (1974) memberi pengertian sehat sakit bahwa seseorang dikatakan sehat apabila keadaannya sempurna, baik fisik, mental, sosial, tidak cacat dan lemah, dan sudah pasti bebas dari penyakit. Sebaliknya, seseorang dikatakan sakit apabila ia menderita penyakit menahun (kronis), atau gangguan kesehatan lain yang menyebabkan aktivitas kerja/kegiatannya terganggu.

Senada dengan pengertian WHO tentang sehat sakit, Perkins (1992) mendefinisikan sehat adalah suatu keadaan seimbang yang dinamis antara bentuk tubuh dan fungsi yang dapat mengadakan penyesuaian sehingga dapat mengatasi gangguan dari luar. Adapun sakit sebagai suatu keadaan yang tidak menyenangkan yang menimpa seseorang sehingga menimbulkan gangguan aktivitas sehari-hari, baik aktivitas jasmani, rohani, dan sosial.

Pada kenyataannya, konsep sehat dan sakit tidak terlalu mutlak dan universal karena ada fakta-fakta lain di luar keadaan klinis yang mempengaruhinya, terutama faktor sosial budaya. Persepsi masyarakat Juntinyuat tentang sehat dan sakit bermacam-macam dan relatif, namun pada umumnya sehat dan sakit berhubungan dengan 2 aspek, yaitu fisik dan psikis. Seorang anak dikatakan dalam keadaan sehat apabila lincah, baik gerakan maupun pikirannya, makannya banyak atau suhu badannya normal. Sebaliknya, seorang anak dikatakan dalam keadaan sakit apabila badannya tampak lemas, lesu, panas, tidak enak badan, atau kalau bayi terus-terusan 
rewel. Berbeda halnya dengan keadaan sehat dan sakit pada orang dewasa. Seseorang dikatakan sehat apabila tidak mempunyai pantangan dalam hal makan, tidak pelupa atau pikirannya bebas.

Berdasarkan pengertian tersebut, maka dapat disimpulkan bahwa sehat atau sakit di masyarakat Juntinyuat menyangkut 3 dimensi, yaitu fisik, psikis, dan sosial. Kondisi fisik dan psikis seseorang, baik sehat maupun sakit, akan berpengaruh pada aktivitas sosialnya. Sebagai contoh, orang yang menderita sakit kepala, selain tersiksa secara fisik, juga akan merasa terusik pikiran dan perasaannya oleh keadaan lingkungan di sekitarnya dan aktivitas sosialnya tidak berjalan sebagaimana mestinya.

Konsep sehat sakit berlaku bagi semua orang, pria wanita, dewasa dan anakanak. Untuk mengetahui seseorang sakit, masyarakat Juntinyuat biasanya mengenalinya lewat pengalaman. Gejala sakit pada anak-anak biasanya ditandai dengan tingkah laku yang gelisah, rewel, sering menangis, tidak mau makan, dan pucat. Sedangkan gejala sakit pada orang dewasa antara lain terlihat letih, lesu, lemah, demam, dan tidak enak badan sehingga mengganggu aktivitas sehari-harinya.

Faktor-faktor yang menyebabkan seseorang dapat terserang sakit, menurut masyarakat Juntinyuat, yaitu:

- Alam,

- Makanan, dan

- Gangguan mahluk halus.

Faktor alam yang menyebabkan sakit berkaitan dengan keadaan cuaca. Cuaca yang biasanya mengganggu kesehatan apabila datang musim hujan, kemarau berkepanjangan, musim peralihan atau pancaroba dari musim hujan ke musim kemarau. Tidak hanya anak-anak, orang dewasa yang keadaan badannya sedang tidak baik atau lemah akan mudah terserang sakit pula. Penyakit-penyakit yang sering diderita karena alam ini seperti demam, flu, batuk, dan masuk angin. Namun demikian, masyarakat Juntinyuat sebagai petani dan nelayan sudah terbiasa dengan keadaan cuaca sehingga tidak mudah sakit.

Faktor makanan yang menyebabkan sakit berkaitan dengan tingkat kebersihan dari makanan. Pengolahan dan penyajian makanan yang tidak memperhatikan kebersihan serta penggunaan bahan campuran bukan untuk makanan bisa menyebabkan sakit. Makanan yang terlampau pedas atau asam berlebihan karena penggunaan cuka yang melewati batas menyebabkan sakit pula. Adapun sakit yang disebabkan oleh makanan di antaranya sakit perut, mualmual, dan mencret. Sakit yang disebabkan oleh faktor makanan biasanya dialami anakanak yang sering jajan sembarangan.

Adapun sakit yang disebabkan oleh mahluk halus, dalam kepercayaan masyarakat Juntinyuat, yaitu sakit yang tidak wajar. Sakit muncul secara tiba-tiba dan tidak diketahui penyebabnya. Menurut kepercayaan masyarakat Juntinyuat ada beragam mahluk halus yang biasa mengganggu manusia sehingga manusia yang ditempelinya menjadi sakit, yaitu:

- Mahluk halus yang baik yang bermaksud mengingatkan atau menyampaikan pesan;

- Mahluk halus dari sesuatu tempat yang menempel di tubuh manusia;

- Mahluk halus yang digunakan oleh manusia untuk menyerang manusia lain yang dikenal dengan istilah pelet, guna-guna, santet, dan teluh.

Fenomena sakit yang disebabkan oleh mahluk halus tidak terjadi pada setiap orang, hanya terjadi pada orang-orang tertentu. Biasanya orang dewasa yang pikirannya kosong atau karena tekanan batin mudah dirasuki mahluk halus. Pemandangan orang-orang yang sudah terganggu pikirannya dijumpai di jalanan sekitar Desa/ Kecamatan Juntinyuat. Untuk mengobati sakit demikian biasanya dengan ilmu kebatinan. Dalam kepercayaan masyarakat Juntinyuat, tumbuhan hanjuang dan palem merah yang ditanam di pekarangan dapat mengusir mahluk halus yang akan masuk ke pekarangan atau rumah.

\section{Sistem Pengobatan Tradisional}

Sistem pengobatan yang dipakai oleh masyarakat Juntinyuat sejak dulu hingga sekarang beragam. Namun demikian, biasanya proses pengobatan dilakukan secara bertahap. Tahap awal pengobatan 
biasanya dengan obat tradisional atau membuat obat sendiri dari tumbuhan. Sebagai contoh, apabila sakit perut yang berakibat mencret-mencret untuk menghentikannya biasanya memakan lalapan dari pucuk daun jambu biji sehingga mencretmencretnya berhenti. Cara lain, dengan meminum air rebusan daun jambu biji. Apabila sakitnya tidak sembuh juga, barulah berobat secara medis. Namun demikian, ada juga sakit yang dapat disembuhkan dengan dipijit oleh tukang urut, seperti masuk angin, urat-urat kaku, dan pegal-pegal.

Dalam kehidupan masyarakat Juntinyuat, sehat dan sakit merupakan hal yang dialami sehari-hari. Sakit tidak dapat dihindari, tetapi dapat dicegah. Pertamakali yang dilakukan apabila sakit pegal-pegal atau masuk angin adalah dengan memijat bagian yang terasa sakit atau seluruh badan dengan menggunakan tangan dan obat yang dapat mengurangi rasa sakit. Apabila perut terasa kembung, maka diurut pada bagian perut. Lain lagi apabila sakit flu, yang dipijat bagian kepala. Pengobatan dengan pijatan juga untuk mengatasi anak susah makan dengan memijat bagian punggung selama 1 jam. Semua pijatan dimaksud untuk melancarkan peredaran darah dan melemaskan urat-urat yang tegang atau dalam istilah setempat brenggol/bronggol. Pengurutan menurut dukun urut disebut "dirapihkan", yaitu pemijatan sebelum berobat secara medis. Bahan yang biasa digunakan dalam memijat di antaranya minyak goreng yang dipanaskan terlebih dahulu atau obat gosok yang bisa dibeli di warung-warung.

Gambar 1: Tukang urut di Desa Juntinyuat
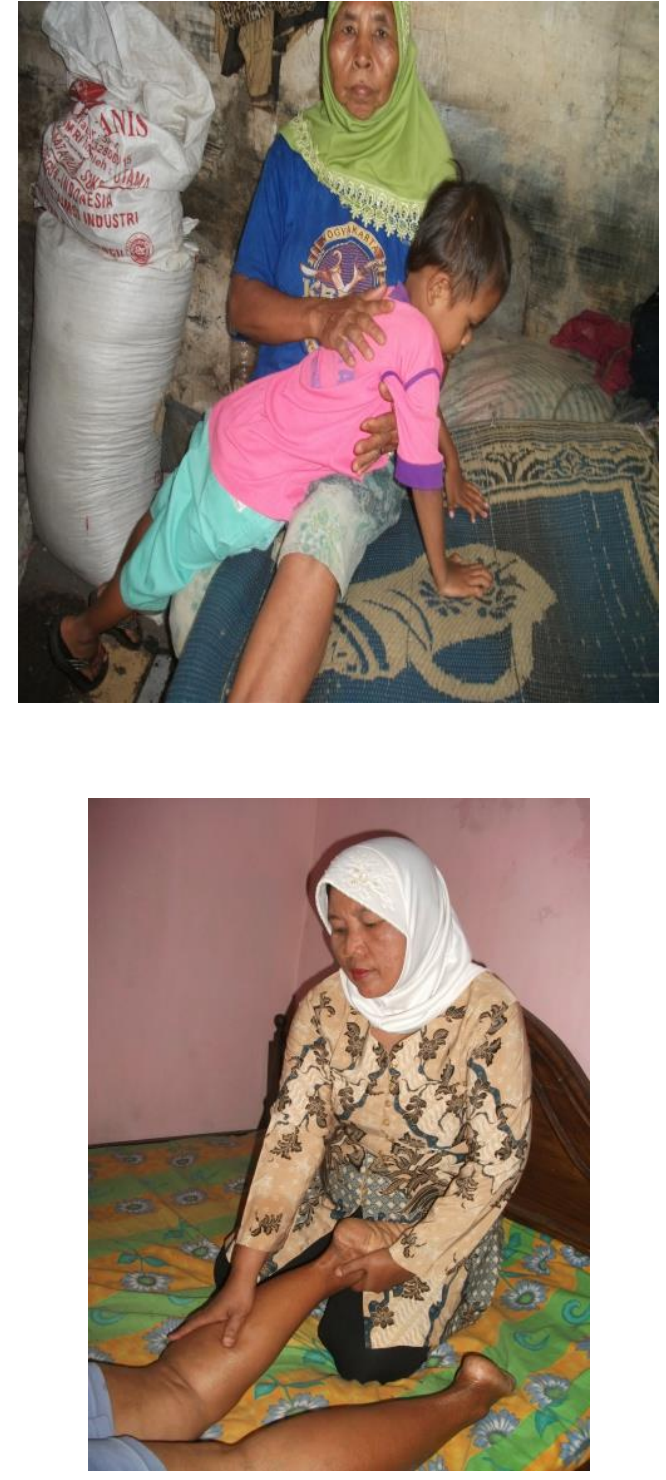

Sumber: Penelitian Tahun 2011

Selain pemijatan, masyarakat Juntinyuat mengenal pula pengobatan dengan bahan obat dari tumbuh-tumbuhan yang pengolahannya berdasarkan pengalaman dari orang tua dengan cara-cara sebagai berikut:

a. Dipipis kemudian dioleskan: daun cocor bebek untuk sakit bisul;

b. Direbus kemudian diminum: pucuk daun jambu untuk sakit mencret;

c. Diparut kemudian dikompreskan: baluh putih mentah untuk penurun panas;

d. Dikunyah kemudian ditelan: pucuk daun pare dan kecap untuk sakit pinggang; 
e. Diulek kemudian diminum: kraca untuk sakit lever;

f. Diperas kemudian diminum: buah pace masak dan madu untuk sakit darah tinggi.

g. Diremas-remas kemudian diminum: seledri untuk sakit darah tinggi.

Sebagian masyarakat di Desa Juntinyuat masih melakukan cara-cara pengobatan tradisional, baik dengan pemijatan maupun ramuan obat dari tumbuh-tumbuhan. Ketika terkilir anggota badan, tidak enak badan, bahkan demam dapat berobat dengan datang kepada tukang pijat atau tukang urut. Sebagian orang mengobatinya dengan ramuan tumbuhan seperti kencur yang diolah seperti tersebut di atas. Hal itu terutama berlaku di kalangan para orang tua yang mewarisi pengetahuan obat dan pengobatan tradisional dari orang tuanya. Pewarisan pengetahuan obat tradisional dapat pula dilakukan antarteman atau antartetangga.

Keahlian mengurut orang sakit di Desa Juntinyuat ini diperoleh secara turuntemurun karena pada umumnya mereka memiliki riwayat keluarga dengan pekerjaan yang sama. Meskipun demikian, tidak setiap orang yang memiliki riwayat demikian dapat melakukannya karena bergantung pada bakat dan minatnya. Oleh karena itu, tukang urut di Desa Juntinyuat ini terbilang langka dan dapat dikatakan hampir punah.

Dalam praktiknya, pengobatan tradisional terkadang dilakukan masyarakat Juntinyuat sebagai langkah awal pengobatan atau sebaliknya sebagai tindak lanjut dari pengobatan secara medis. Misalnya, sakit demam diperiksa dulu di puskesmas. Apabila keterusan sakitnya, baru dibawa ke tukang urut. Sebaliknya, sakit karena keseleo, terkilir, atau patah tulang biasanya ditangani terlebih dahulu oleh tukang urut, selanjutnya secara medis.

Adapun pengobatan dengan ramuan tumbuhan dapat dilakukan sendiri berdasarkan pengalaman. Berbagai jenis tumbuhan yang selama ini digunakan mayarakat, baik dalam pengobatan maupun pemeliharaan kesehatan, khasiatnya sudah terbukti yang mendorong mereka mengembangkan tanaman obat keluarga atau TOGA, baik di rumah masing-masing maupun yang dikelola oleh PKK. Berbagai jenis tumbuhan yang ditanam sudah dipraktikkan sebagai bahan obat, diantaranya adalah pisang klutuk ungu, remujung, melandingan atau bendara, mata dewa, kangkung, handeuleum, jambu biji, kencur, lidah buaya, katuk, delima putih, kunyit, bugenfil, salam, jeruk purut, pete, daun jati, alang-alang, meniran, kumis kucing, kecibeling, kesembung, tempuyung, kraca, ciplukan, pepaya gandul, dringo bengle, kikoneng, kluwih, pace atau mengkudu, seledri, ketumbar, dan pare.

Gambar 2: Bapak Karsan di tengah kebun obat yang dikelolanya.

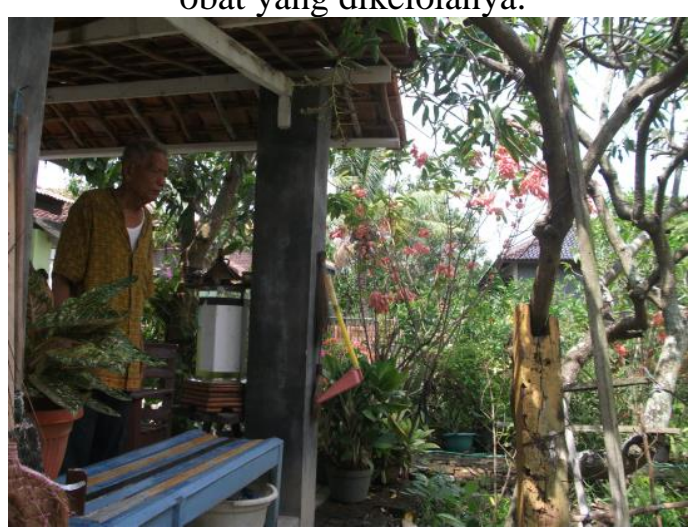

Sumber: Penelitian tahun 2011

\section{Jenis dan Khasiat Tanaman Obat \\ a. Belimbing Wuluh (Averrhoa Bilimbi L.)}

Belimbing wuluh selain digunakan sebagai bahan makanan juga berkhasiat untuk mengobati tekanan darah tinggi. Adapun daunnya dapat mengobati sakit lever dengan mencampurkan daun kesumbung dan daun alpukat.

\section{b. Baluh Putih}

Baluh putih biasanya digunakan sebagai bahan sayur yang rasanya dingin. Namun demikian, baluh putih bagi masyarakat Juntinyuat dapat digunakan sebagai obat penurun panas. Caranya, baluh putih yang masih muda diparut kemudian dikompreskan pada jidat atau bagian badan lainnya yang berasa panas.

\section{c. Beluntas (Pluchea Indica)}

Beluntas atau pluchea indica merupakan tumbuhan yang banyak dijumpai di pedalaman Juntinyuat yang dimanfaatkan sebagai pagar hidup rumah-rumah penduduk 
yang belum menggunakan pagar besi. Biasanya tumbuhan tersebut dapat tumbuh secara liar. Beluntas berkhasiat sebagai obat, diantaranya untuk mengobati penyakit reumatik dan menghilangkan bau badan. Adapun bagian tumbuhan yang dapat digunakan sebagai bahan obat adalah akar dan daunnya.

Untuk obat rematik, dipakai akarnya sebanyak 15 gram akar beluntas. Setelah dicuci sampai bersih, direbus dengan air sekitar 2 gelas hingga tersisa 1 gelas. Daun beluntas juga dapat dimakan sebagai lalab dan dapat menghilangkan keluhan bau badan.

\section{d. Bendara/Melandingan}

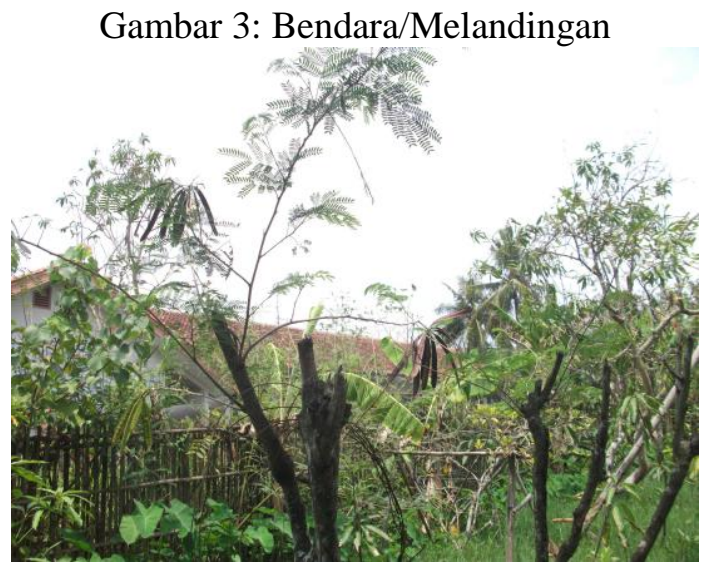

Sumber: Penelitian Tahun 2011

Bendara atau melandingan adalah tumbuhan yang sekilas mirip lamtoro gung. Perbedaannya dengan lamtoro gung, bendara lebih kecil, batang tidak keras dan dapat digunakan sebagai bahan kertas. Daunnya bersifat majemuk dan kecil-kecil. Demikian pula buahnya bersifat majemuk seperti biji yang berderet pada setiap tandan. Bendara bagi masyarakat Juntinyuat bermanfaat sebagai obat sakit mata, kencing manis, cacingan, dan paru-paru basah. Adapun bagian yang digunakan untuk obat sakit mata dan kencing manis, yaitu buahnya.

Cara membuat obat dengan mengeluarkan buah bendara dari kulitnya, kemudian dicuci. Setelah kering buah bendara disangrai atau digoreng tanpa minyak. Selanjutnya, bendara tersebut diulek, lalu diseduh dengan 1 gelas air panas. Seduhan tersebut diminum $1 \mathrm{x} 1$ sendok teh.
Reaksi dari minum seduhan tersebut akan terasa setelah 3 hari, mata menjadi terang. Untuk pengobatan kencing manis, cacingan, dan paru-paru basah, cara pengobatannya sama dengan cara pengobatan sakit mata.

\section{e. Beringin Putih}

Beringin putih memiliki daun berwarna putih kehijauan. Akarnya bagi masyarakat Juntinyuat dapat dimanfaatkan sebagai obat batuk dengan meminum air rebusan akar beringin putih tersebut.

\section{f. Brotowali (Tinospora Crispa)}

Brotowali atau tinospora crispa sejenis tumbuhan yang merambat. Biasanya, tumbuhan tersebut merambat sepanjang pagar. Brotowali banyak kegunaannya bagi kesehatan, di antaranya batang brotowali bagi masyarakat Juntinyuat dimanfaatkan sebagai obat reumatik. Caranya, 1 jari batang brotowali dicuci dipotong-potong lalu direbus dengan 3 gelas air hingga tersisa 1,5 gelas, kemudian disaring dan ditambahkan madu. Air rebusan brotowali tersebut diminum 3 kali sehari sebanyak $1 / 2$ gelas.

\section{g. Bugenfil (Bougenvillea Glabra)}

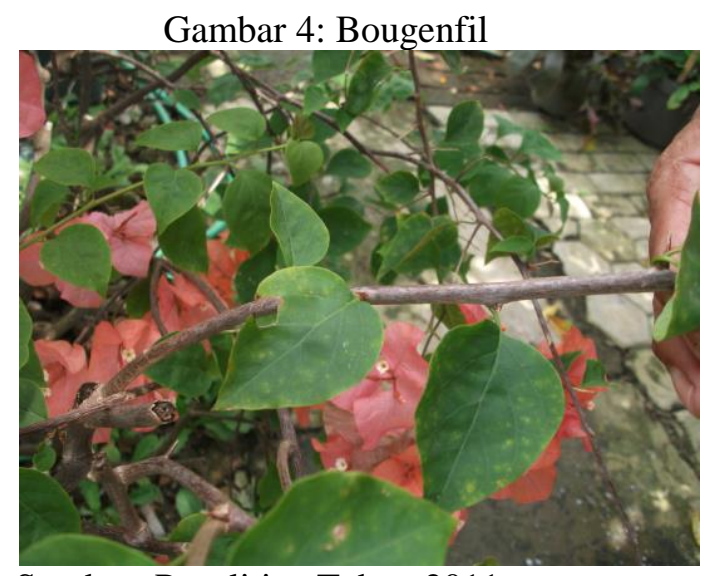

Sumber: Penelitian Tahun 2011

Bugenfil atau bougenvillea glabra merupakan tumbuhan perdu, tumbuh secara menahun dengan tinggi sekitar 5-15 meter. Tumbuhan ini berkhasiat mengobati penyakit lever. Bagian yang digunakan adalah batangnya. Caranya, batang Bugenfil dipukulpukul menggunakan alat untuk menggerus, kemudian direbus. Setelah dingin, air rebus- 
an diminum 2 kali sehari masing-masing 1 gelas.

\section{h. Delima Putih (Punica Granatum L.)}

Gambar 5: Delima Putih

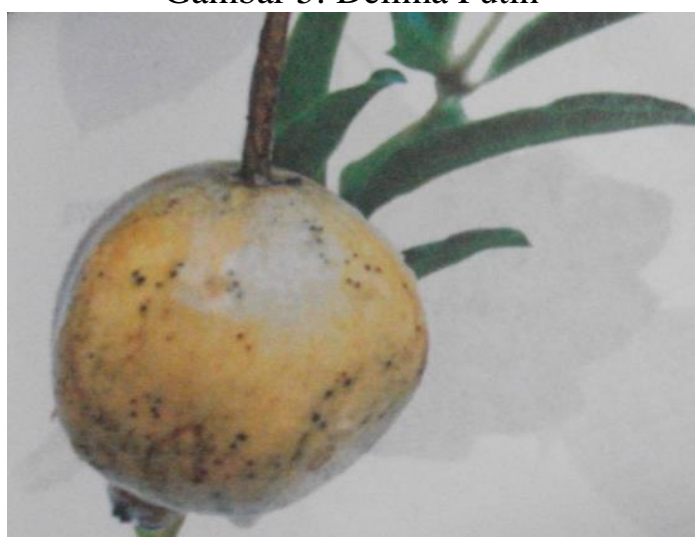

Sumber: Intisari Tahun 1998

Delima putih atau punica granatum banyak terdapat di Kabupaten Indramayu. Tinggi pohon sekitar 2-5 meter. Delima putih berhkasiat untuk mengobati penyakit prostat. Bagian yang digunakan adalah buah atau daunnya. Caranya, daun delima putih 1 tangkai atau sebanyak 1 genggam dicampur buahnya direbus dengan air. Air rebusannya diminum 2 kali sehari 1/4 gelas.

Khasiat lain delima putih adalah obat sakit cacingan, khususnya karena cacing pita. Caranya, akar delima putih bersama bawang putih digerus sampai halus, tambahkan air matang secukupnya, saring, lalu diminum.

\section{i. Handeuleum (Graptophylum Pictum Griff)} Gambar 6: Handeuleum

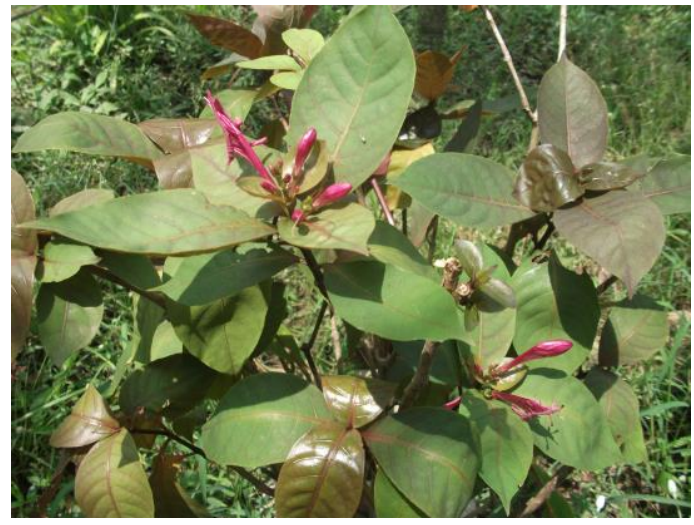

Sumber: Penelitian Tahun 2011

Handeuleum atau daun wungu (ungu) adalah tanaman berakar tunggal dan berbatang keras. Daun mudanya berwarna merah, sedangkan daun tuanya berwarna hijau gelap. Tanaman handeuleum berkhasiat untuk mengobati berbagai penyakit. Di antaranya parises, ambeien, dan susah buang air besar. Caranya, daun handeuleum muda 5 lembar direbus dengan 2 gelas air hingga tersisa 1 gelas, kemudian diminum 1 kali pada pagi hari. Cara lain, daun handeuleum muda dapat dimakan sebagai lalap cukup 3 lembar saja. Selain untuk mengobati penyakit tersebut, juga untuk mengobati radang otak dan sulit tidur.

\section{j. Jambu Biji (Psidum Guajava)}

Jambu biji atau dalam bahasa Latin psidium guajava dapat tumbuh secara liar atau sengaja ditanam. Ciri fisik tumbuhan berbatang kayu, serat daun keras saling bertemu, buahnya bulat berbiji banyak. Jambu biji terdapat dua jenis, yaitu jenis buah berdaging putih dan berdaging merah.

Daun jambu biji berkhasiat mengobati gangguan kandung kemih atau beser. Bagian yang diambil adalah pucuk daunnya. Caranya, 2 sendok makan beras yang sudah disangrai didihkan dengan 1 gelas air, setelah mendidih masukkan pucuk daun jambu. Setelah dingin baru diminum.

\section{k. Kangkung (Ipommoea Aquatica Forsk)}

Kangkung sudah tidak asing bagi kita karena kerap menjadi teman makan nasi yang menyegarkan apabila dimakan panaspanas dan menggunakan bumbu cabai. Kangkung yang dalam bahasa Latin ipommoea aquatica forsk pertumbuhannya dapat dibilang cepat sekitar 4 sampai 6 minggu sudah diap dipanen. Tempat tumbuhnya bisa di darat atau di air. Ciri-ciri fisik tumbuhan memiliki tinggi atau panjang 30-50 sentimeter, menjalar dengan daun berselang. Bentuk daun seperti mata panah, lebar, dan tirus. Meskipun demikian, kangkung air dan kangkung darat memiliki perbedaan. Kangkung air berbunga putih kemerahan, sedangkan kangkung darat berbunga putih bersih. Kangkung air berbatang dan daunnya lebih lebar daripada daun pada kangkung darat. Kangkung berkhasiat mengobati masalah susah tidur. Caranya sederhana dengan dimakan sebagai lalap, dimasak bumbu oseng, dibuat urab atau dibuat lotek. 


\section{Katuk (Sauropus Androgynus)}

Katuk atau nama Latinnya sauropus androgynus merupakan tumbuhan sayur yang tinggi pohonnya sampai 3 meter. Biasanya dapat dipetik setelah 2 tahun. Daunnya kecil berwarna hijau tua karena mengandung banyak klorofil. Bunganya berwarna merah gelap atau kuning dengan bercak merah gelap. Pucuk daun katuk dapat dimakan dalam bentuk sayur bening. Bagi ibu yang baru melahirkan, daun katuk muda bermanfaat untuk memperlancar keluarnya air susu ibu.

\section{m. Kelapa (Cocos Nucifera L.)}

Kelapa muda banyak terdapat di Juntinyuat pesisir. Selain dapat dimakan langsung, kelapa ini dapat dimanfaatkan sebagai obat muntah-muntah dengan merebusnya terlebih dahulu bersama-sama bawang putih, laos, dan gula merah.

\section{n. Kencur (Kaemferia Galanga)}

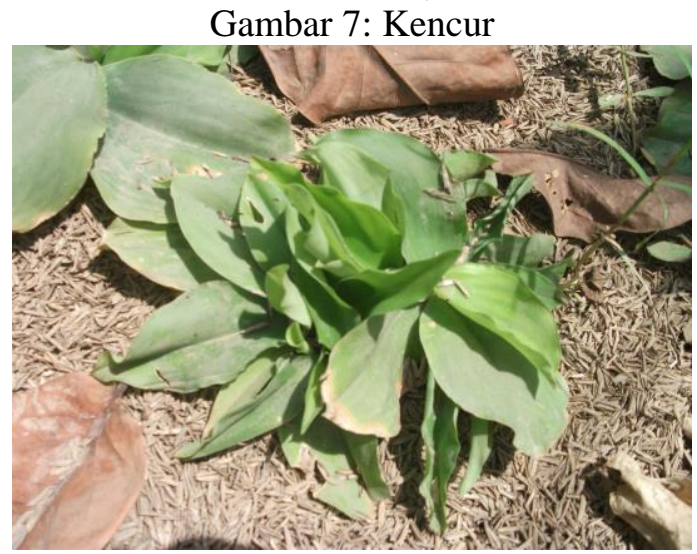

Sumber: Penelitian Tahun 2011

Kencur atau dalam bahasa Latin disebut kaemferia galanga merupakan tumbuhan jenis umbi-umbian. Tumbuhan ini cukup unik karena tingginya tidak lebih dari 10 sentimeter, umbinya pun tidak lebih dari 1 ruas jari dewasa. Meskipun demikian, kencur berkhasiat obat selain sebagai bumbu masakan, seperti urab, ulukutek leunca, atau penambah rasa pada lotek.

Adapun bagian yang sering digunakan untuk obat, bagian daunnya. Daun kecur berkhasiat untuk mengobati sakit maag. Untuk obat, dicampur bersama beras. Caranya, beras secukupnya dicuci terlebih dahulu, lalu disangrai. Selanjutnya, tambahkan 1 gelas air lalu direbus. Setelah mendidih masukkan daun kencur secukupnya. Setelah dingin baru diminum.

\section{o. Kunyit (Curcuma Domestica)}

Kunyit atau curcuma domestica merupakan tumbuhan yang memiliki banyak khasiat. Kunyit yang juga disebut kunir bersifat mendinginkan, membersihkan, melepaskan kelebihan gas di usus, menghentikan pendarahan, dan melegakan hidung tersumbat.

Kunyit selain dikenal sebagai bahan bumbu untuk menghasilkan warna kuning, juga berkhasiat untuk mengobati sakit maag. Caranya, kunyit setelah dicuci sampai bersih diparut, ditambah air matang, lalu diperas. Air perasannya diminum 2 kali sehari selama 1 bulan.

\section{p. Lidah Buaya (Aloe Vera)}

Lidah buaya atau aloe vera hanya mempunyai batang pokok yang pendek berkisar $80-100$ sentimeter, daunnya berwarna hijau muda, bentuk meruncing ke ujung, berbintik bulat, kedua sisi batang berduri, serta berisi lendir. Lendir tersebut berkhasiat mengobati berbagai macam penyakit selain dapat dibuat manisan, dodol/ wajit, atau gel untuk kecantikan.

Adapun penyakit yang dapat diobati dengan lidah buaya adalah radang tenggorokan, ambeien, dan panas dalam. Caranya, sebatang lidah buaya dicuci, dikupas, lalu lendirnya dikerok. Kemudian lendir lidah buaya dicampur sirup secukupnya, barulah diminum.

\section{q. Matadewa}

Tanaman matadewa berkhasiat untuk sakit mata. Tanaman ini berbunga putih. Bunganya dapat dijadikan obat dengan cara bunga dicelupkan ke dalam air, kemudian teteskan ke mata yang sakit. Reaksi obat tersebut pedih.

\section{r. Melati (Jasminum Sambac Ait)}

Melati merupakan jenis bunga yang semerbak sehingga sering dipakai sebagai pengharum ruangan. Selain itu, sering digunakan sebagai pelengkap upacara tradisional. Namun demikian, melati bagi 
masyarakat Juntinyuat dapat dimanfaatkan pula sebagai obat untuk melangsingkan badan.

\section{s. Nangka}

Akar nangka dapat dimanfaatkan sebagai obat malaria dengan meminum air rebusannya.

t. Pisang Klutuk Ungu

\section{Gambar 8: Pisang Klutuk Ungu}

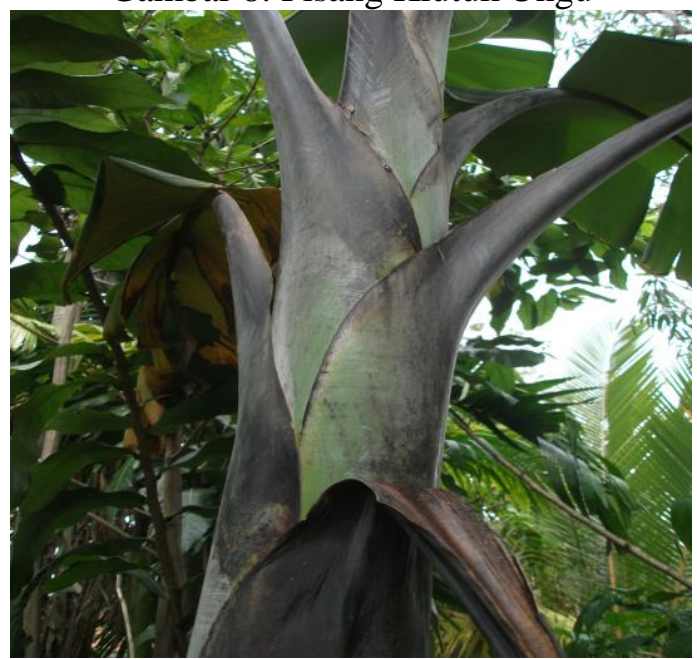

Sumber: Penelitian Tahun 2011

Pisang dalam bahasa Latin disambiguasi merupakan makanan sehari-hari yang sudah tidak asing bagi masyarakat Juntinyuat. Dalam kehidupan sehari-hari, pisang biasa dimakan sebagai pencuci mulut atau dimakan setelah makan nasi. Pada umumnya, buah pisang berwarna kuning ketika sudah matang, namun ada beragam jenis pisang yang ketika matang berwarna jingga, merah, hijau, ungu, dan hampir hitam. Adapun pisang berwarna ungu atau pisang klutuk ungu dalam masyarakat Juntinyuat dapat dimanfaatkan sebagai obat. Di antaranya sebagai obat darah tinggi dan penurun panas.

Sebagai obat penurun tekanan darah yang digunakan adalah bonggolnya. Cara pengolahan dengan melubangi bagian tengah bonggol sehingga keluar cairan berwarna merah dari dalam bonggol tersebut. Cairan tersebut diminum $2 \times 2$ sendok makan.

Sebagai obat penurun panas digunakan juga bagian bonggol. Caranya, bonggol dihancurkan atau disisir kemudian direbus dengan $1 \frac{1}{2}$ gelas air hingga tersisa $1 / 4$ gelas, diminum 2 × 2 sendok makan. Minum air rebusan tersebut hingga sembuh.

\section{u. Remujung}

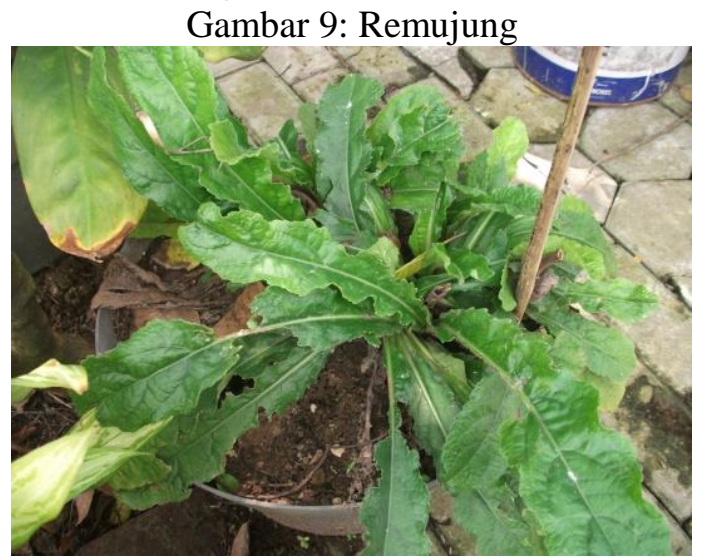

Sumber: Penelitian Tahun 2011

Remujung dalam istilah lokal masyarakat Juntinyuat dikenal kumis kucing atau brengos kucing. Tumbuhan ini memiliki tinggi sekitar 1,5 meteran, tumbuh di daerah lembab, batang basah berbentuk empat persegi dan mudah dipatahkan. Daunnya berbentuk bulat telur, bunga berwarna putih dengan bentuk seperti kumis seekor kucing. Remujung atau istilah Latinnya orthosiphon stamineus benth berkhasiat mengobati prostat atau batu ginjal. Bagian yang digunakan untuk obat adalah daunnya. Sebagai obat daun remujung 5 lembar bersama-sama daun handeuleum dan daun sirih masing-masing 5 lembar direbus dengan 4 gelas air hingga tersisa $1 / 2$ gelas. Setelah dingin diminum pagi dan sore 2 x sehari. Reaksi dari minum rebusan tersebut dalam 24 jam akan lancar buang air besar.

\section{v. Salam (Syzygium Polyanthum)}

Salam atau nama Latinnya syzygium polyanthum merupakan tumbuhan dengan daun tunggal. Tingginya dapat mencapai 30 meter. Daunnya dikenal sebagai bahan bumbu masakan, seperti sayur kacang. Namun demikian, daun salam berkhasiat sebagai obat penyakit darah tinggi. Daun salam dapat menurunkan tekanan darah yang tinggi. 
Sebagai obat penurun tekanan darah tinggi, daun salam dihaluskan dengan cara digerus bersama-sama ketumbar, kemudian direbus dengan 2 gelas air hingga tersisa 1 gelas, setelah dingin air rebusan tersebut diminum 2 kali sehari.

\section{w. Randu (Ceiba Petandra Bakh)}

Randu dalam bahasa Latin ceiba petandra bakh. Daun randu atau dalam istilah setempat daun buta berkhasiat untuk mengobati sakit sariawan atau panas dalam. Caranya: daun randu secukupnya dicuci bersih lalu diperas hingga keluar cairannya. Kemudian dicampur air matang secukupnya lalu diminum. Akar randu dapat pula digunakan sebagai penurun suhu badan yang sedang panas dengan cara dtumbuk lalu diberi air selanjutnya diminum.

Randu merupakan sejenis pohon yang tingginya bisa mencapai 25 meter. Batang dan cabang pohon randu berduri. Buahnya berbentuk lonjong, bila sudah matang akan mengering dan terbelah sehingga keluar kapuk berwarna putih. Penanaman randu dengan bijinya yang banyak terdapat diantara kapuk dan tumbuhnya cepat.

\section{PENUTUP}

Berdasarkan hasil penelitian tentang Sistem Pengobatan Tradisional di Desa Juntinyuat, Kecamatan Juntinyuat, Kabupaten Indramayu, maka dapat disimpulkan sebagai berikut.

Konsep sakit bagi masyarakat Juntinyuat adalah keadaan tidak seimbang unsur fisik (lemas, demam), psikis (emosi terganggu), dan sosial (hubungan sosial terganggu). Hal tersebut selaras dengan konsep makrokosmos dan mikrokosmos bahwa alam adalah makrokosmos dan manusia adalah mikrokosmos, apabila hubungan manusia dengan alam tidak harmonis maka akan terjadi ketidak-seimbangan. Badan manusia dapat pula diibaratkan makrokosmos dan mikrokosmos yang mengandung air, udara, dan tanah. Apabila unsur udara berlebihan, air berlebih-an, atau unsur tanah berlebihan, maka akan terjadi ketidakseim- bangan dalam tubuh sehingga manusia merasa sakit.

Masyarakat Juntinyuat melakukan pengobatan secara tradisional dengan mengolah tumbuh-tumbuhan menjadi obat karena leluhurnya sudah mewariskan pengetahuan tersebut. Jadi mereka meneruskan yang sudah ada karena manfaatnya sudah dirasakan secara turun-temurun. Selain itu, pengobatan tradisional tidak menimbulkan kerusakan pada organ tubuh tidak seperti halnya obat modern.

Pengetahuan pengobatan tradisional merupakan tradisi warisan leluhur masyarakat Juntinyuat yang hingga kini masih bertahan. Praktik pengobatan tradisional tersebut tampak dalam kegiatan upacara tradisional dan kehidupan seharihari. Misalnya, upacara barita untuk menolak wabah penyakit yang menyerang manusia dan upacara mapag tamba untuk mengusir hama yang akan menyerang tanaman padi. Dalam upacara tersebut dilakukan pencegahan menggunakan air dari berbagai sumber dengan dimanteramanterai.

Desa Juntinyuat memiliki sumber alam yang subur, baik dari hasil laut maupun pertanian. Hal itu mempengaruhi pola makan masyarakatnya yang setiap hari mengonsumsi ikan asin dan sayuran. Pola makan yang berlebihan ditambah faktorfaktor lainnya berpengaruh buruk pada keseimbangan badan yang menyebabkan seseorang sakit. Penyakit yang banyak dikeluhkan pun merupakan efek dari pola makan seperti darah tinggi, reumatik, dan maag.

Pengobatan tradisional yang diterapkan oleh masyarakat Juntinyuat menempuh 2 cara, yaitu dengan pijat atau urut dan menggunakan tumbuh-tumbuhan (herbal). Pengobatan dengan pijat atau urut biasanya digunakan saat sakit ringan, seperti masuk angin atau pegal-pegal. Biasanya tukang urut mengiringi pijatannya dengan doa-doa agar pijatannya dapat menyembuhkan pasien. Adapun ramuan obat dari tumbuh-tumbuhan biasanya digunakan untuk mengobati sakit berat, seperti liver, kencing manis, kencing batu, darah tinggi, reumatik, dan asam urat. Herbal untuk pengobatan luar biasanya digerus atau 
diremas lalu ditapelkan pada anggota badan yang sakit. Adapun untuk pengobatan dalam biasanya bagian tumbuhan yang digunakan tersebut direbus terlebih dahulu, lalu airnya diminum.

Pengobatan tradisional, baik dengan urut maupun herbal pada masyarakat Juntinyuat hingga kini terus dilakukan di samping pengobatan secara modern. Upaya ke arah sosialisasi pengetahuan warisan leluhur, baik secara perorangan maupun kelompok sudah tampak dengan adanya tukar-menukar pengalaman dan mendokumentasikannya. Hasilnya, memotivasi masyarakat Juntinyuat untuk menanam tumbuh-tumbuhan yang berkhasiat di lingkungan tempat tinggal mereka, di antaranya brotowali yang berkhasiat untuk mengobati sakit reumatik, kunyit untuk maag, pace untuk darah tinggi, pisang klutuk ungu untuk darah tinggi, remujung untuk prostat, dan sambiloto untuk TBC.

1. Saran

Mengingat obat-obatan yang berasal dari herbal telah diakui oleh dunia medis, maka pemerintah hendaknya melakukan sosialisasi tumbuhan berkhasiat kepada masyarakat, baik di perkotaan maupun pedesaan, agar penanaman tumbuh-tumbuhan yang berkhasiat lebih digalakkan. Selain itu, pemerintah membekali masyarakat pengetahuan meracik tumbuhan ber-khasiat menjadi obat melalui pelatihan-pelatihan dan simulasi.
1. Buku

Djlantik. 1983.

Peranan Pengobatan Tradisional pada Upaya Pelayanan Kesehatan dalam Sistem Kesehatan Nasional dalam Pertemuan Ilmiah Pengobatan Tradisional Indonesia. Jakarta: Lembaga Penelitian Universitas Erlangga.

Daulay, Zainul. 2011.

Pengetahuan Tradisional Konsep, Dasar Hukum, dan Praktiknya. Jakarta: Rajawali Pers.

Iskandar, Johan dan Budiawati S. Iskandar. 2005.

Pengobatan Alternatif Ala Baduy. Bandung: Humaniora.

Isnandar, Wahid. 2007.

Kumpulan 1001 Ramuan Obat Tradisional Indonesia. Mojokerto: Dayang Sumbi.

Koentjaraningrat. 2007.

Sejarah Teori Antropologi II. Jakarta: UI Press.

Purnama, Yuzar dkk. 2004.

Budaya Tradisional pada Masyarakat Indramayu. Bandung: Balai Kajian Sejarah dan Nilai Tradisional.

\section{Majalah}

Intisari Cetakan I, November 1998. Jakarta: Intisari Mediatama.

Trubus 507, Februari 2012/XLIII. Jakarta.

Pengobatan Alternatif Solusi Kesehatan Plus Cermat dan Tuntas Cetakan I/02, 2005: Jakarta: Penebar Swadaya 